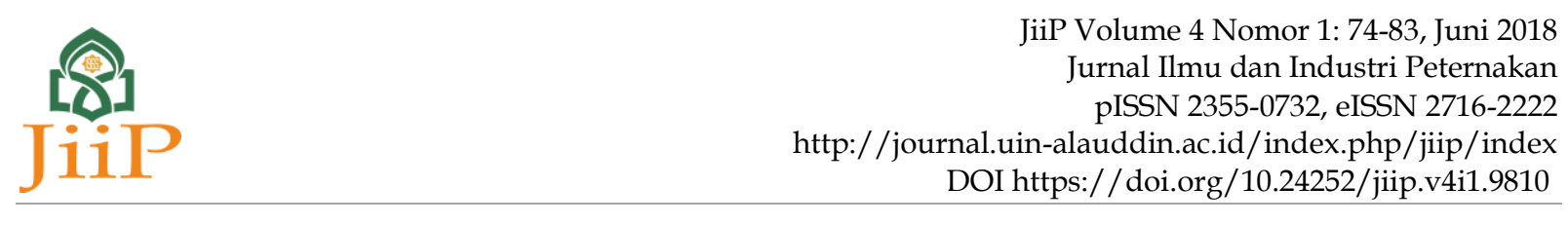

\title{
Strategi Pengendalian dan Pencegahan Penyebaran Virus Highly Pathogenic Avian Influenza pada Sektor III dan IV di Kabupaten Polewali Mandar, Sulawesi Barat
}

\author{
Policy of Control and Prevention the Spread of Highly Pathogenic Avian influenza \\ Virus in Sector III and IV in Polewali Mandar Regency, West Sulawesi
}

\author{
Aminah Hajah Thaha', Isnaniah Bagenda ${ }^{2}$ \\ 1Jurusan Ilmu Peternakan Fakultas Sains dan Teknologi \\ Universitas Islam Negeri Alauddin Makassar \\ ${ }^{2}$ Dinas Pertanian Kabupaten Polewali Mandar \\ Email : amina.hajah@uin-alauddin.ac.id
}

\begin{abstract}
ABSTRAK
Kabupaten Polewali Mandar merupakan kabupaten dengan jumlah populasi ternak unggas ayam kampung dan ayam pedaging (broiler) tertinggi di Provinsi Sulawesi Barat yaitu masing-masing sebesar 1.723.253 ekor dan 885.200 ekor. Hal inilah yang menyebabkan angka kematian unggas akibat Highly Pathogenic Avian influenza (HPAI) juga tinggi dibandingkan kabupaten lainnya. Berbagai kendala dihadapi dalam pelaksanaan kegiatan pengendalian dan pencegahan tersebut, sehingga menuntut pemerintah setempat untuk mengambil kebijakan yang efektif dan efisien. Tujuan dari penelitian ini yaitu mengidentifikasi langkahlangkah pengendalian dan pencegahan penyebaran virus Highly Patogenic Avian influenza pada Sektor III dan IV di Kabupaten Polewali Mandar Sulawesi Barat. Berdasarkan hasil penelitian diketahui bahwa Strategi Pengendalian dan Pencegahan Penyebaran Virus Highly Pathogenic Avian influenza pada Sektor III dan IV di Kabupaten Polewali Mandar yang telah diterapkan antara lain (a) Deteksi, Lapor dan Respon (DLR) Cepat, (b) Biosekuriti, (c) vaksinasi, (d) Penataan/Sanitasi Rantai Pasar Unggas, (e) Pengawasan Lalu Lintas Unggas, dan (f) Komunikasi, Informasi dan Edukasi (KIE).
\end{abstract}

Kata kunci: Highly Pathogenic Avian influenza, Pengendalian dan Pencegahan, Strategi

\begin{abstract}
Polewali Mandar Regency has the highest number of local chicken and broiler population in West Sulawesi Province, which are 1,723,253 and 885,200. High Pathogenic Avian influenza (HPAI) is also higher in Polewali Mandar Regency compared to other districts caused high mortality rate. Various obstacles were found in control and prevent Highly Pathogenic Avian influenza, thus the local government needs to take effective and efficient policies. The aim of this study is to identify how the policies in control and prevent the spread of Highly Patogenic Avian Influenza virus in Sector III and IV in Polewali Mandar District, West Sulawesi. Results of the study, it is known that the Strategy of Virus Spread Control and Prevention of Highly Pathogenic Avian influenza in Sector III and IV in Polewali Mandar District that has been implemented are (a) Rapid Detection, Reporting and Response (DLR), (b) Biosecurity, (c) Vaccination, (d)
\end{abstract}


Arrangement/Sanitation of Live Bird Market Chain, (e) Monitoring of Poultry Traffic, and (f) Communication, Information and Education (CIE).

Keywords: Control and Prevention, Highly Pathogenic Avian Influenza, Policy

\section{PENDAHULUAN}

Highly Pathogenic Avian influenza (HPAI) atau yang lebih umum di kenal dimasyarakat sebagai Flu Burung merupakan salah penyakit hewan menular strategis berdasarkan Surat Keputusan Menteri Pertanian Nomor : 4026/Kpts/OT.140/4/2013 Tentang Penetapan Jenis Penyakit Hewan Menular Strategis yang sudah ada di Indonesia.

Menurut Thaha, A. et al (2018) Virus Highly Pathogenic Avian influenza (HPAI) mulai menyebar di Provinsi Sulawesi Barat pada tahun 2005, Kabupaten yang tertular saat itu adalah Kabupaten Polewali Mandar dan Majene. Berdasarkan pemeriksaan sampel di lapangan, hingga saat ini seluruh Kabupaten Se Sulawesi Barat sudah tertular virus Highly Pathogenic Avian influenza (HPAI). Virus ini merupakan ancaman serius bagi berbagai pihak karena sifatnya yang sangat mudah bermutasi dan menyebar sehingga dapat berdampak terhadap perekonomian masyarakat dan kesehatan masyarakat.

Menurut Badan Pusat Statistik Provinsi Sulawesi Barat (2018) bahwa Kabupaten Polewali Mandar merupakan Kabupaten dengan jumlah populasi ternak unggas ayam kampung dan ayam pedaging (broiler) tertinggi di Provinsi Sulawesi Barat yaitu masingmasing sebesar 1.723.253 ekor dan 885.200 ekor (Gambar 1). Ternak ayam kampung di Kabupaten Polewali Mandar seluruhnya merupakan skala usaha peternakan pada sektor 4 yaitu pemeliharaan dengan jumlah 1-10 ekor dengan sistem pemeliharaan ekstensif dan semi ekstensif, sedangkan ayam pedaging (broiler) merupakan skala usaha peternakan pada sektor 3 yaitu pemeliharaan dengan jumlah 10-10.000 ekor dengan sistem pemeliharaan intensif.

Melihat potensi populasi ternak ungags yang disajikan pada Gambar 1. tidak mengherankan berbagai langkah penanggulangan penyakit hewan menular strategis telah dilaksanakan oleh pemerintah mulai dari pusat, provinsi, hingga kabupaten untuk mengurangi berbagai dampak yang ditimbulkan. Berbagai kendala dihadapi dalam pelaksanaan kegiatan pengendalian dan pencegahan tersebut, sehingga menuntut pemerintah setempat untuk mengambil kebijakan yang efektif dan efisien. Berdasarkan uraian tersebut diatas, maka penelitian "Kebijakan Pengendalian dan Pencegahan Penyebaran Virus Highly Patogenic Avian influenza pada Sektor III dan IV di Kabupaten 
Polewali Mandar" dilakukan agar diperoleh suatu informasi mengenai langkah-langkah dalam penanggulangan wabah HPAI di Kabupaten Polewali Mandar sehingga dapat dijadikan referensi untuk permasalahan serupa di daerah lain.

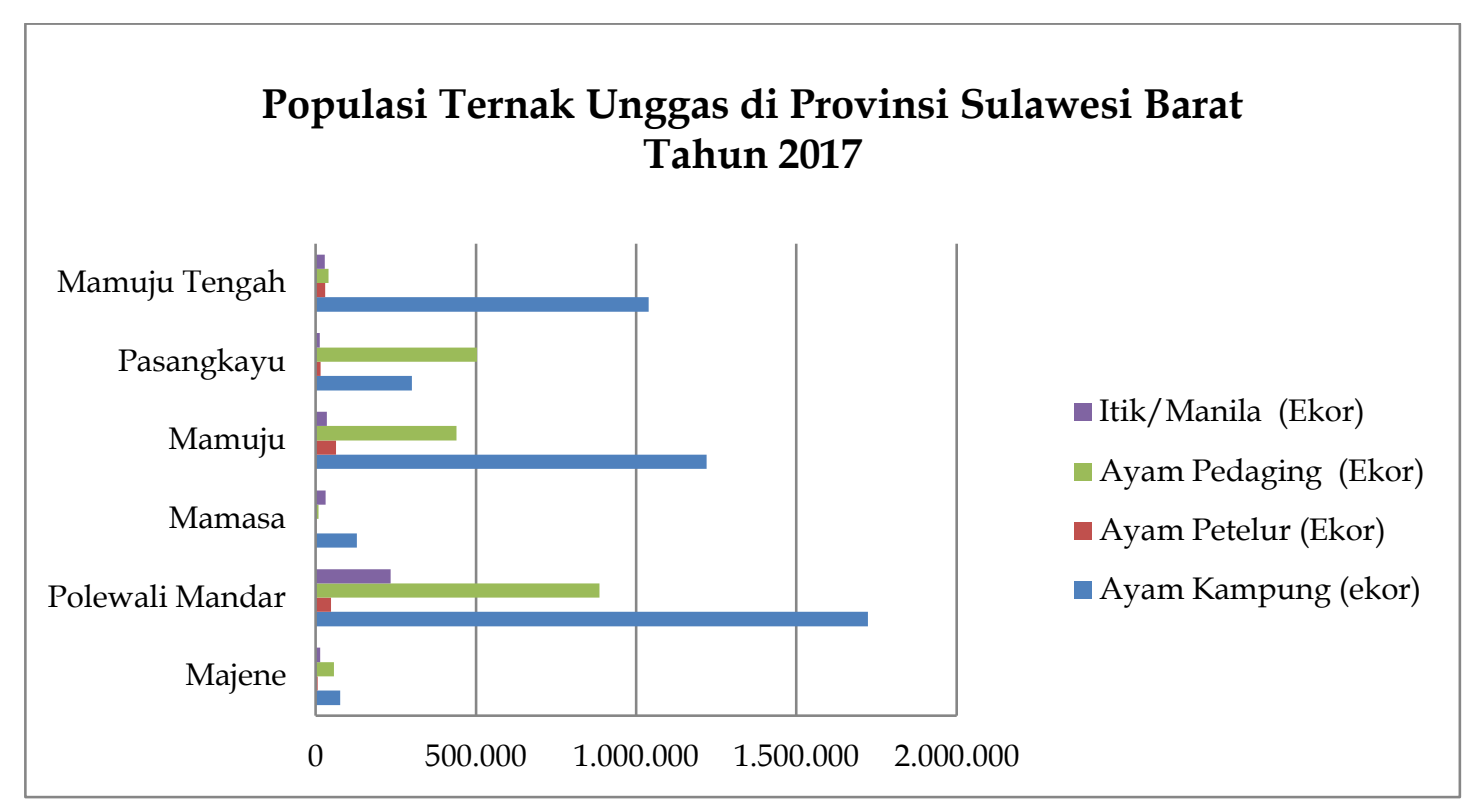

Gambar 1. Populasi Ternak Unggas di Provinsi Sulawesi Barat Tahun 2017

Berdasarkan latar belakang yang telah diuraikan diatas, maka rumusan masalahnya adalah bagaimana Kebijakan Pengendalian dan Pencegahan Penyebaran Virus Highly Patogenic Avian influenza pada Sektor III dan IV di Kabupaten Polewali Mandar Sulawesi Barat. Tujuan dari penelitian ini, yaitu mengidentifikasi langkah-langkah pengendalian dan pencegahan penyebaran virus Highly Patogenic Avian influenza pada Sektor III dan IV di Kabupaten Polewali Mandar Sulawesi Barat. Hasil penelitian ini diharapkan dapat dijadikan sebagai sumber informasi kepada para pengambil kebijakan dan petugas teknis di lapangan yang berperan aktif dalam Pengendalian dan Pencegahan Penyebaran Virus Highly Patogenic Avian influenza.

\section{MATERI DAN METODE}

\section{Jenis dan Lokasi Penelitian}

Jenis penelitian ini adalah penelitian kualitatif yang merupakan field research. Lokasi penelitian adalah di Kabupaten Polewali Mandar Provinsi Sulawesi Barat. Penelitian ini 
dilakasanakan pada tanggal 1 Mei sampai dengan 14 Mei 2018 bertempat di Kabupaten Polewali Mandar Provinsi Sulawesi Barat.

\section{Sumber dan Metode Pengumpulan Data}

Sumber data dalam penelitian kualitatif diperoleh dari informan kunci yang menjadi pelaku utama antara lain Kepala Dinas, Kepala Bidang Peternakan, Kepala Pusat Kesehatan Hewan dan Staf, dan Tim Surveilans dan Respon Cepat Penyakit AI, selain itu juga peternak unggas komersil sektor III, dan peternak unggas sektor IV. Teknik pengambilan sampel dilakukan secara purposive. Jenis data dalam penelitian ini terdiri atas dua, yaitu data Primer dan data Sekunder.

Metode pengumpulan data terdiri dari observasi, wawancara, dan dokumentasi. Adapun teknik yang dilakukan dengan wawancara tidak terstruktur dan wawancara terstruktur.

\section{HASIL DAN PEMBAHASAN}

Pemerintah Republik Indonesia telah mengeluarkan kebijakan melalui Surat Keputusan Direktur Jenderal Peternakan Nomor : 05018/Kpts/PD.610/ f/12/2008 Tentang Perubahan Lampiran Keputusan Direktur Jenderal Peternakan Nomor : 45/Kpts/PD.610/F/06.06 Tentang Prosedur Operasional Standar Pengendalian Penyakit Avian influenza di Indonesia, menjelasakan bahwa dalam rangka pengendalian wabah penyakit Avian influenza di Indonesia, Departemen Pertanian telah mencanangkan sembilan langkah strategis pengendalian meliputi : (1) penerapan biosekuriti secara ketat, (2) depopulasi selektif di daerah tertular, (3) vaksinasi, (4) pengendalian lalu lintas, (5) surveillans dan penelusuran, (6) peningkatan kesadaran masyarakat (public awarness), (7) pengisian kembali (restocking) unggas, (8) stamping out di daerah tertular baru dan (9) monitoring, pelaporan, dan evaluasi. Diharapkan sembilan langkah strategis tersebut dapat diimplementasikan secara lebih efektif, utuh, dan terpadu oleh Dinas yang membidangi fungsi peternakan dan kesehatan hewan dan masyarakat (Ditjen Peternakan, 2008 : 7).

Pemerintah juga kembali mengeluarkan Surat Edaran Direktur Jenderal Peternakan dan Kesehatan Hewan No. 04041/PK.310/F.III/2016 tanggal 4 November 2016 dan Surat Edaran Direktur Kesehatan Hewan No. 30034/PK.320/F4/01/2017 tanggal 30 Januari 2017 tentang Peningkatan Kewaspadaan dan Pengendalian Penyakit Hewan Menular Strategis (PHMS), antara lain : 
1. Penyuluhan kepada masyarakat agar melapor ke petugas kesehatan terdekat bila mengetahui adanya unggas sakit/mati mendadak

2. Tindakan 3 Cepat (Deteksi, Lapor dan Respon Cepat Pengendalian Penyakit)

3. Penerapan Biosekuriti dengan model 3 Zona (Bersih, Antara, Kotor) guna mengamankan peternakan agar tidak terserang masuknya berbagai kuman penyakit unggas

4. Penerapan Vaksinasi 3 Tepat (Vaksin, Jadwal, Tehnik vaksinasi)

5. Tindakan Sanitasi pada sepanjang rantai pemasaran unggas

6. Surveilans investigasioleh Laboratorium Veteriner guna mengetahui sumber penularan, epidemiologi dan dinamika virus AI

7. Kompartementalisasi dan zona bebas AI

8. Masyarakat menerapkan Perilaku Hidup Bersih Sehat (PHBS) Masyarakat

Merujuk pada berbagai kebijakan pemerintah tersebut diatas, pembahasan pada penelitian ini dibatasi hanya pada strategi yang telah di laksanakan di Kabupaten Polewali Mandar.

\section{Deteksi, Lapor dan Respon (DLR) Cepat}

Deteksi merupakan suatu sistem yang bertujuan untuk mengetahui perkembangan trend suatu penyakit hewan menular disuatu wilayah dalam periode waktu tertentu yang selanjutnya akan dilaporkan dan di respon secara cepat. Salah satu cara mendeteksi penyakit hewan menular yaitu melalui surveilans aktif dan pasif ke lokasi-lokasi yang dianggap berpotensi untuk menyebarkan penyakit ternak. Salah satu langkah yang dilakukan terkait Deteksi, Lapor dan Respon (DLR) Cepat adalah dibentuknya Tim PDSR (Parsipatory Disease Surveillans and Respons) pada Tahun 2009 sampai dengan Tahun 2013. Setelah itu kembali dibentuk Tim Respon Cepat yang terdiri dari petugas pusat kesehatan hewan (medik veteriner dan paramedik veteriner). Para prinsipnya seluruh petugas tersebut melaksananakan surveilans dan monitoring kasus ke lokasi kejadian untuk mengetahui tingkat keberhasilan tindakan pengendalian dan pencegahan.

Seiring dengan kemajuan teknologi, saat ini pemerintah telah memiliki sistem pelaporan terintegrasi yaitu iSIKHNAS (Sistem Informasi Kesehatan Hewan Nasional Terpadu). Menurut Anonimous (2017) bahwa iSIKHNAS merupakan sistem informasi kesehatan hewan Indonesia berbasis online yang berfungsi untuk mengumpulkan data kasus yang diperoleh dari petugas medik veteriner dan paramedivet terlatih secara cepat 
dan akurat di lapangan. Data tersebut dapat setiap saat diakses oleh para pengambil kebijakan sehingga dapat digunakan untuk pengambilan keputusan khususnya dapat pemberantasan suatu penyakit di wilayahnya masing-masing.

Kabupaten Polewali Mandar saat ini telah memiliki 3 unit Pusat Kesehatan Hewan yang tersebar di 3 Kecamatan. Jumlah personil yaitu dokter hewan sebanyak 1 orang dan paramedivet sebanyak 18 orang. Keterbatasan jumlah personil yang bekerja di lapangan tidak sebanding dengan luas wilayah sebesar 2.022,30 Km² yang terdiri dari 16 kecamatan (Badan Pusat Statistik Kabupaten Polewali Mandar, 2018), sehingga melalui iSIKHNAS sistem pelaporan menjadi efektif karena kasus penyakit bisa lebih cepat diperoleh sehingga respon pengendalian dan pencegahan lebih cepat dilakukan unuk melokalisir penyebaran penyakit tersebut. Para petugas di lapangan juga dibantu oleh relawan - relawan desa terlatih yang berada di wilayah dengan tingkat kejadian tinggi. Adapun Alur Informasi iSIKHNAS dapat dilihat pada Gambar 2.

Sejumlah petugas yang melaksanakan surveillans dan penelusuran secara aktif maupun pasif telah mengikuti berbagai pelatihan oleh Kementrian Pertanian, Food and Agriculture Orgnization (FAO), Departement Agriculture, Fisheries, and Forestry (DAFF) Australia, dan Pemerintah Provinsi Sulawesi Barat.

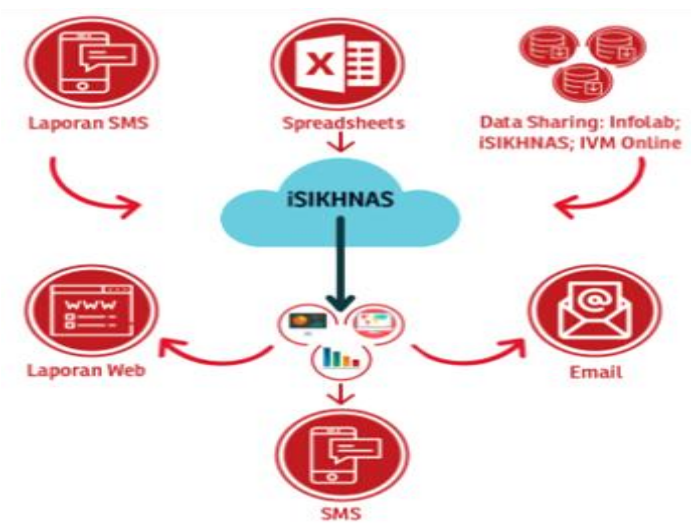

Gambar 2. Alur Informasi iSIKHNAS

(Sumber:http://wwwtest.isikhnas.com/public/index.php/ 2017/06/21/ apaeistimewaan-isikhnas/)

\section{Biosekuriti}

Peternakan unggas sektor 4 umumnya merupakan peternak unggas pekarangan dengan jenis ternak berupa ayam kampung dengan kepemilikan rata-rata 1-10 ekor per rumah tangga. Menurut Badan Pusat Statistik Kabupaten Polewali Mandar (2018), Populasi 
ayam kampung yang terbesar di Kabupaten Polewali Mandar berada di Kecamatan Campalagian sebesar 249.528 ekor dan di Kecamatan Wonomulyo sebesar 213.588 ekor. Biosekuriti pada Peternakan unggas sektor 4 di Kabupaten Polewali Mandar umumnya masih sangat lemah, menurut Ilham (2015) bahwa salah satu yang menjadi penyebab lemahnya biosecurity pada sektor 4 adalah keterbatasan dana sehingga peternak tidak mampu menerapkan biosecurity yang efisien dan efektif.

Salah satu cara yang dilakukan oleh pemerintah setempat ada pembentukan dan pembinaan kelompok tani ternak utamanya di wilayah dengan populasi ternak unggas yang tinggi. Hal ini sesuai dengan arahan Ditjennak (2006) bahwa salah satu cara untuk mewujudkan Village Poultry Farming (VPF) atau Budidaya Unggas Pedesaan yaitu melalui penguatan kelembagaan kelompok ternak unggas lokal, sehingga populasi dari unggas lokal setempat juga ikut meningkat. Kegiatan yang sering dilaksanakan secara bersama-sama dengan masyarakat adalah melaksanakan program biosekuriti melalui desinfeksi dengan target unggas pekarangan serta Menyelenggaran Sosialisasi Biosecuriti berbasis desa kepada masyarakat bekerjasama dengan melibatkan seluruh jajaran Kesehatan Hewan Kabupaten, Aparatur desa/Kelurahan Badan penyuluh dimasing - masing kabupaten.

Biosekuriti unggas sektor 3 di Kabupaten Polewali Mandar dari tahun ke tahun semakin baik. Setidaknya masing-masing peternakan telah memiliki pagar yang menjadi barrier agar mobilitas di dalam peternakan tersebut lebih dapat dikontrol. Berdasarkan hasil wawancara, diketahui bahwa Pemerintah Kabupaten Polewali Mandar juga pernah menyelenggaran Pelatihan Biosecuriti berbasis Unggas Komersil kepada masyarakat bekerjasama dengan melibatkan seluruh jajaran Kesehatan Hewan Kabupaten, Aparatur desa/Kelurahan Badan penyuluh.

\section{Vaksinasi}

Kebijakan Pemerintah Kabupaten Polewali Mandar terkait vaksinasi pada unggas di sektor 4 saat ini adalah tidak melaksanakan vaksinasi. Hal ini dianggap kurang efektif karena sistem pemeliharan di sektor 4 yang sebagian besar masih secara ekstensifikasi atau di umbar. Pengkandangan unggas bertujuan untuk mencegah penularan dan penyebaran penyakit dari dan ke lingkungan, selain itu untuk memudahkan vaksinasi dan memonitoring hasil vaksinasi tersebut (Suwito et al., 2013). Pada peternakan sektor 3 pemerintah hanya sebatas menyarankan penggunaan vaksin AI, meskipun demikian hampir seluruhnya telah melaksanakan vaksinasi AI karena pola usaha yang dijalani oleh 
peternak yaitu kemitraan sehingga program vaksinasi bisa dijalankan sesuai dengan aturan yang tepat. Minimnya informasi yang diterima dan dimiliki baik oleh Dinas Peternakan kabupaten maupun provinsi sehingga akses ke peternakan - peternakan komersil sulit. Untuk itu dibutuhkan suatu program pengendalian tidak hanya di peternakan sektor 4 (unggas pekarangan) peternakan unggas komersil.

Vaksinasi merupakan salah satu alternatif dalam pencegahan AI pada unggas. Menurut Suwito et al. (2013), vaksin AI cukup protektif dalam melindungi unggas pekarangan (sektor 4) terhadap penyakit AI selama 2 minggu pascavaksinasi pertama. Untuk itu vaksinasi AI pada unggas dianggap efektif untuk mengurangi penularan dan penyebaran penyakit AI.

\section{Penataan/Sanitasi Rantai Pasar Unggas}

Pasar di Kabupaten Polewai Mandar hampir seluruhnya masih menjual unggas hidup (ayam kampung, itik, ayam broiler, dll) yang berasal dari berbagai wilayah dalam dan luar Kabupaten Sulawesi Barat. Pasar ini tentu saja menjadi salah satu faktor resiko yang berpotensi menularkan virus HPAI, terutama jika konsumen membeli unggas hidup yang terjangkit virus dan dalam masa inkubasi. Berdasarkan hasil penelitian Ratnawati dan Dharmayanti (2015) terhadap identiikasi virus H5N1 yang menyebabkan HPAI, diketahui bahwa pasar unggas hidup merupakan lingkungan yang cocok untuk Virus H5N1 berpindah dan berkembang biak karena berbagai jenis unggas seperti ayam kampung, ayam broiler, dan itik sebagai reservoir dijual bersama-sama sehingga dapat terjadi genetic mixing. Hasil pemeriksaan PCR membuktikan bahwa titik cemaran penyebaran virus H5N1 pada unggas di pasar tradisional adalah kandang penampungan penjualan itik dan broiler (Helmi et al., 2015). Titik cemaran inilah yang berperan terhadap penyebaran virus H5N1 ke lingkungan sekitarnya.

Pemerintah setempat belum melaksanakan secara utuh penataan sanitasi rantai pasar unggas, salah satu kendala yang dihadapi adalah minimnya sarana prasarana yang memadai sehingga salah satu langkah antisipasi yang dilakukan pelaksanaan desinfeksi pada pasar unggas khususnya pada saat hari pasar berlangsung.

\section{Pengawasan Lalu Lintas Unggas}

Pengawasan lalu lintas ternak menjadi hal yang mutlak untuk mengawasi ternak yag keluar masuk dari dari/ke Kabupaten Polewali Mandar. Saat ini telah ditetapkan oleh Dinas setempat petugas pengawas lalu lintas ternak pada masing-masing pos penjagaan di daerah 
perbatasan. Kegiatan yang dilaksanakan dalam rangka antisipasi penyebaran virus AI adalah melakukan desinfeksi kendaraan yang mengangkut unggas dari luar wilayah pada pos lalu lintas ternak.

Melakukan pengawasan lalu lintas ternak baik antar provinsi maupun antar kabupaten dipintu - pintu perbatasan bekerjasama dengan Dinas Perhubungan. Kendaraan yang secara administrasi tidak melengkapi SKKH (Surat Keterangan Kesehatan Hewan) diberikan sanksi mulai dari teguran hingga mengembalikan ternak tersebut ke daerah asal.

\section{Komunikasi, Informasi dan Edukasi (KIE)}

Komunikasi, Informasi dan Edukasi (KIE) merupakan suatu upaya yang dilaksanakan dalam jangka pendek maupun panjang oleh sekelompok orang dengan tujuan mengubah, mengganti, atau memperkenalkan ide-ide, gagasan, kepercayaan, atau perilaku terhadap sekelompok orang (Hapsari dan Setiawan, 2008). Dalam hal ini yang merupakan kelompok target adalah peternak unggas dan masyarakat yang beresiko terhadap penularan AI.

Berdasarkan penelitian yang dilakukan oleh Said et al. (2010) diketahui bahwa terjadi perbaikan dan peningkatan pengetahuan, sikap dan praktek peternak menganai tata cara pencegahan dan pengendalian Avian influenza setelah diberikan intervensi komunikasi, informasi, dan pendidikan terkait hal tersebut. KIE merupakan salah satu kegiatan pencegahan yang sering dilaksanakan oleh pemerintah setempat, adapun bentuk KIE yang diberikan kepada masyarakat dan aparatur desa terkait penyakit Avian influenza berupa sosialiasi pertemuan tatap muka dan penyebaran leaflet yang dititik beratkan pada mekanisme pelaporan dini, pencegahan, dan penanganan bangkai unggas. Dengan demikian diharapkan masyakarat turut berpartisipasi dalam pencegahan dan pengendalian Avian influenza di Kabupaten Polewali Mandar.

\section{KESIMPULAN}

Strategi Pengendalian dan Pencegahan Penyebaran Virus Highly Pathogenic Avian influenza pada Sektor III dan IV di Kabupaten Polewali Mandar yang telah diterapkan antara lain (a) Deteksi, Lapor dan Respon (DLR) Cepat, (b) Biosekuriti, (c) vaksinasi, (d) Penataan/ Sanitasi Rantai Pasar Unggas, (e) Pengawasan Lalu Lintas Unggas, dan (f) Komunikasi, Informasi dan Edukasi (KIE). Selanjutnya perlu disarankan beberapa hal, yaitu 1) Pemerintah Kabupaten Polewali Mandar memfasilitasi Pembentukan Asosiasi Peternak Unggas Se Kabupaten Polewali Mandar sebagai sarana untuk perbaikan struktur 
perunggasan di Kabupaten Polewali Mandar utamanya rantai pemasaran unggas hidup maupun produk hasil peternakan seperti daging dan telur, 2) Peningkatan pelaksanaan Komunikasi, Informasi, dan Edukasi (KIE) di masyarakat dan pelaku sektor perunggasan khususnya di wilayah-wilayah dengan kepadatan populasi unggas yang tinggi, dan 3) Peningkatan sarana dan prasarana yang mendukung tata laksana higiene sanitasi di pasar Unggas.

\section{DAFTAR PUSTAKA}

Anonimous. 2017. Apa Keistimewaan Isikhnas ?. (Online), (http://wwwtest.isikhnas.com/public/ index.php/2017/06/21/apa-keistimewaanisikhnas/, di Akses tanggal 5 Mei 2018).

Badan Pusat Statistik Provinsi Sulawesi Barat. 2018. Provinsi Sulawesi Barat dalam Angka 2018. BPS Provinsi Sulawesi Barat. CV. Prima Digi, Mamuju.

Badan Pusat Statistik Kabupaten Polewali Mandar. 2018. Kabupaten Polewali Mandar dalam Angka 2018. BPS Kabupaten Polewali Mandar. Auliyah Polewali, Polewali.

Ditjennak. 2006. Pedoman Program Village Poultry Farming-VPF. Jakarta (Indonesia): Direktorat Jenderal Peternakan.

Hapsari, H. dan Setiawan, I. 2008. Kajian model komunikasi, informasi, dan edukasi. Jurnal Kependudukan Padjadjaran, Vol. 10 (1).

Helmi, T.F., Yulisma, R., Panjaitan, B., Tabbu, C.R., dan Haryanto, A. 2015. Deteksi dan identifikasi cemaran virus avian influenza pada pasar tradisional di Kabupaten Aceh Besar dan Kota Banda Aceh. Jurnal Sain Veteriner

Ilham, Nyak. 2015. Kebijakan Pemerintah terhadap Usaha Unggas Skala Kecil dan Kesehatan Lingkungan di Indonesia. Wartazoa, 25 (2).

Ratnawati, A dan Dharmayanti, N.L.P.I. 2015. Deteksi virus avian influenza subtipe H5N1 di beberapa pasar unggas hidup dalam wilayah Provinsi Jawa Barat sekitarnya. Jurnal Kedokteran Hewan, 9 (1).

Said, R. M., Thaha, M. R., dan Syafar, M. 2010. KIE untuk peningkatan pengetahuan, sikap, dan praktik pencegahan dan penanggulangan penyakit flu burung di Kabupaten Gowa, Sulawesi Selatan. Jurnal Kesehatan Masyarakat Nasional, Vol. 5 (1).

Suwito, W., Supriadi, Winarti, E., dan Primatika, R.A. 2013. Kajian vaksin avian influenza (AI) pada ayam buras dengan sistem kandang kurung di Gunung Kidul Yogyakarta. Sains Peternakan, 11 (2).

Thaha, A. H., Rauf, J., and Bagenda, I. 2018. Mapping the spread of avian influenza virus in poultry at Polewali Mandar Regency, 2008-2013. Journal of the Indonesian Veterinary Research, 2 (1) : 19-26. 